\title{
5.4 Креолізація рекламних повідомлень у сфері косметології (на матеріалі японської і української мов)
}

Пропоновану статтю присвячено дослідженню особливостей взаємодії вербального і невербального компонентів у сучасних японських та українських рекламних повідомленнях. Звернено увагу на специфіку рекламних повідомлень у сфері косметології. Основний зміст дослідження становить аналіз креолізації рекламних повідомлень 3 метою встановлення кореляцій мови реклами 3 параметрами менталітету і культури двох народів. Виявлено, що зображення займають більшу частину друкованої площини рекламного повідомлення, ніж текст, що свідчить про домінуюче положення візуального компонента у рекламі косметичної продукції. Проаналізовано тенденції щодо локалізації реклами і виявлення в рекламному повідомленні самобутності народу, його культури.

Сучасна лінгвістика звернула свою увагу на семіотично гетерогенні тексти, для опису яких ще не розроблений загальновизнаний термінологічний апарат і які, в найбільш загальному вигляді, звуться креолізованими [422, с. 165]. Зупинимося більш детально на змісті цього терміна, який орієнтовано на специфіку рекламного тексту. Термін "креолізований текст" було введено Ю.О. Сорокіним і Є.Ф Тарасовим, які розглядають його як текст, "фактура якого складається 3 двох негомогенних частин: вербальної (мовної/мовленнєвої) і невербальної (яка належить до інших знакових систем, ніж природна мова)" [423, с. 180-186].

О.Е. Анісімова визначає креолізований текст як "особливий лінгвовізуальний феномен, у якому вербальні і іконічні висловлення" створюють одне візуальне, структурне, змістовне і функціональне ціле, яке комплексно впливає на адресата [420, с. 148]. 3 огляду а те, що мовний і візуальний компоненти постають у певній взаємодії, Л.В. Головина виділяє три види кореляції тексту і зображення:

1) паралельна: зміст тексту і зображення повністю збігаються;

2) комплементарна: невербальна інформація частково перекриває вербальну;

3) інтерпретативна: інформація і текст пов'язані за змістом [421]. 
Ми розглядаємо креолізовані тексти, представлені рекламними повідомленнями, в яких зміст складається із нерозривного поєднання зображення та вербальної інформації.

овний рівень використовується для прив’язки повідомлення, тому що візуальний образ часто виявляється двозначним і може тлумачитися по-різному. У візуальній комунікації У. Еко виділяє n’ять кодифікаційних рівнів:

1) тонічний рівень, коли розуміємо, що та чи інша конфігурація зображує кота чи стілець і не задаємо питання, чому це так, а не інакше;

2) іконографічний рівень, при якому перед нами два типи кодифікації: одна - історичного типу, в якій рекламне повідомлення використовує конфігурації, що відсилають до певних значень, прийнятих класичною іконографією (від німбу, який означає святість, до поєднання фігур, пов’язаних з ідеєю материнства тощо); друга, яка склалася в рекламі, як такої, коли, наприклад, жінка, яка стоїть у характерній позі нога за ногу, повинна зображувати манекенницю;

3) рівень тропів включає візуальні еквіваленти словесних тропів. Троп може бути несподіваним, може набувати естетичного значення або може бути спробою візуального відтворення словесної метафори. 3 іншого боку, мова реклами використовує такі тропи візуальної комунікації, які буває важко звести до словесних;

4) рівень топосів: рівно включає як область так званих передумов, так і загальних місць аргументації, або топосів, тобто дві рубрики, за якими традиційно розподілялися аргументи. Кодифікація топосів могла б перетворитися на детальну класифікацію способів передачі словесних топосів візуальними образами. При аналізі

мови зображень стає очевидним наявність іконограм, що індукують ціле поле топосів;

5) рівень ентимем - це рівень аргументації як такої. У зв’язку 3 багатозначністю зображення і необхідністю закріпити за ним одне значення за допомогою слів, аргументація виходить або із словесного ряду, або їі джерелом є співвіднесення словесного ряду з візуальним [424]. 
Метою даної статті $є$ встановлення кореляції вербального i невербального компонентів у сучасних японських і українських рекламних повідомленнях у сфері косметології.

Рекламний текст як продукт комбінації знаків різних семіотичних систем принципово не відрізняється від гомогенного вербального тексту, йому притаманні ті ж самі текстові категорії - цілісність та зв'язність. Для належного декодування інформації, закладеної в полікодовому тексті, потрібно сприймати текст цілісно, беручи до уваги інтеграцію знаків як вербальної, так і невербальної семіотичних систем. Але між цими компонентами встановлюються автосемантичні відношення, де вербальна частина порівняно автономна від зображувальної. Іконографічні частини рекламних повідомлень, з одного боку, допомагають уникнути багатозначності, а 3 іншого, підсилює образність повідомлення.

Використання різних мовних і позамовних засобів, які репрезентують маніпулятивні прийоми в рекламних текстах, базується, за нашими спостереженнями, на низці популярних тем і мотивів, що становлять цінність для сучасної людини та її менталітету, який її формує: вступ у нове століття, прогрес, престижність, а також о́брази привабливих чоловіків і жінок, родини, пріоритети здорового способу життя, здоров'я загалом тощо. Лінгвальні і екстралінгвальні стратегії рекламного тексту створюють єдине структурне, візуальне, семантичне і функціональне ціле, яке забезпечує необхідний ефект рекламного повідомлення.

В українських рекламних повідомленнях косметичних засобів зображувальні елементи присутні у 100 \% текстів. Серед яких можемо виділити:

- зображення обличчя жінки (зазвичай знаменитість) разом із продукцією;

- візуалізачія метафоричного вербального компонента;

-іконічні знаки; 
- візуалізачія вербальних знаків.

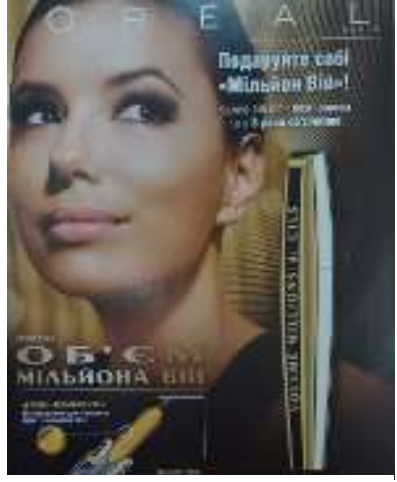

Рис 1.

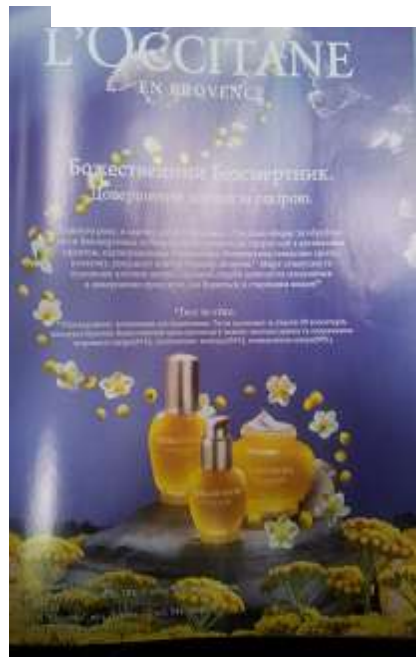

Рис. 2

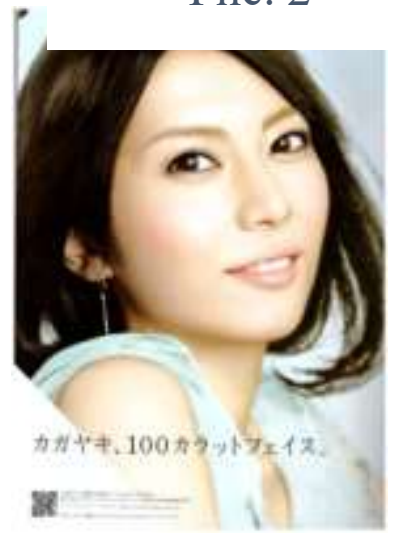

Рис.3

У цьому рекламному повідомленні спостерігаємо одразу два засоби: фото селебріті (Сва Лонгрія) і візуалізацію метафоричного вербального компонента (мільйон вій). Ефект сугестії забезпечується завдяки подвійному впливу на читача за допомогою фото обличчя відомої зірки і зображення “мільйона вій ”(рис.1).

На рис. 2 спостерігаємо метафоричну візуалізацію вербального компонента "Божествений Безсмертник" у вигляді сяючого світла 3 неба і доріжки 3 квіток, яка піднімається вверх. В Україні, як зрештою і в інших православних країнах світу, безсмертя асоціюється із вознесінням Ісуса Христа на небо на третій день після казні. В даному випадку вербальний компонент уточнює іконічний знак неба. А завдяки ефекту візуалізації, малюнок підсилює інформацію тексту.

В японських рекламних повідомленнях у сфері косметології також відмічаємо тенденцію щодо використання фото жіночого обличчя для доказу ефективності того чи іншого косметичного засобу. Вербальний компонент “100カラットフェイス” можна перекласти як обличчя у сто каратів. В даному випадку візуальний компонент домінує над вербальним, оскільки фото гарного жіночого обличчя $\epsilon$ дієвим доказом ефективності косметичного засобу (рис.3). 


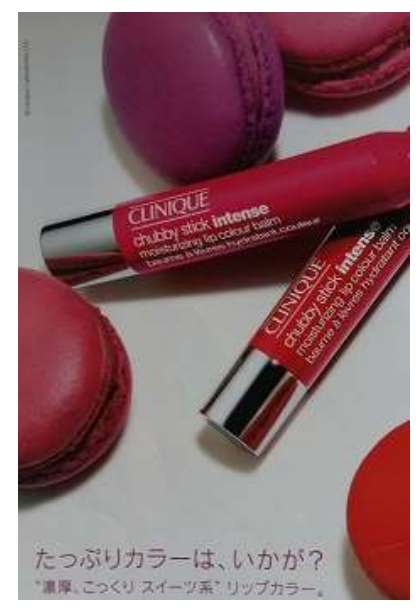

Рис. 4

На рис. 4 зображена помада фірми CLINIQUE, що корелює із кольором відомих і популярних в сучасній Японії солодощів макарон, які також присутні на сторінці рекламного повідомлення.. Вербальний компонент スイー ツ系 /suitsukei/ вказує на походження кольору помади, а відтак, що губи за насиченістю кольору і смаком будуть нагадувати найбажаніші солодощі.

Поняття іконічний знак вперше було запропоновано американським філософом і логіком Чарлзом Пірсом. За Пірсом, іконічний знак - це "знак, який має певні властивості означуваного ним об’єкта, незалежно від того, чи існує цей об'єкт в реальності". Іконічний знак - це поняття, яке пов'язане 3 зображенням будь-яких предметів, тварин, птахів, символів, орнаментів, персонажей тощо . Іконографічні частини рекламних повідомлень, з одного боку, допомагають уникнути багатозначності, а 3 іншого, підсилюють образність повідомлення. Під іконічними також розуміємо знаки, які базуються на відтворенні подібності між знаком та його значенням за кольором, формою, звучанням, структурою чи послідовністю. Зв'язність рекламного тексту проявляється в узгодженні і тісному взаємозв'язку вербального та іконічного компонентів на змістовому, змістово-мовному та змістово-композиційному рівнях. Знак виконує найважливішу функцію суспільної комунікації - якщо людина не знайома із суспільно обумовленими значеннями, прийнятими в цьому суспільстві і культурі символічного значення кольору або предмета, то комунікація або не відбудеться, або стане істотно ускладненою. Тому декодування цих знаків надає нам інформацію про суспільство і культуру певного народу.

В українських рекламних повідомленнях косметичної продукції виділяємо:

- іконічні знаки (67,8\%);

- вербалізовані іконічні знаки $(1,4 \%)$. 
Як приклад розглянемо рекламне повідомлення антивікової сироватки фірми VICHY. Після вислову Сьогодні я буду їсти на ходу бачимо іконічний знак - гамбургер. У різних країнах і культурах існує своя традиційна вулична їжа.

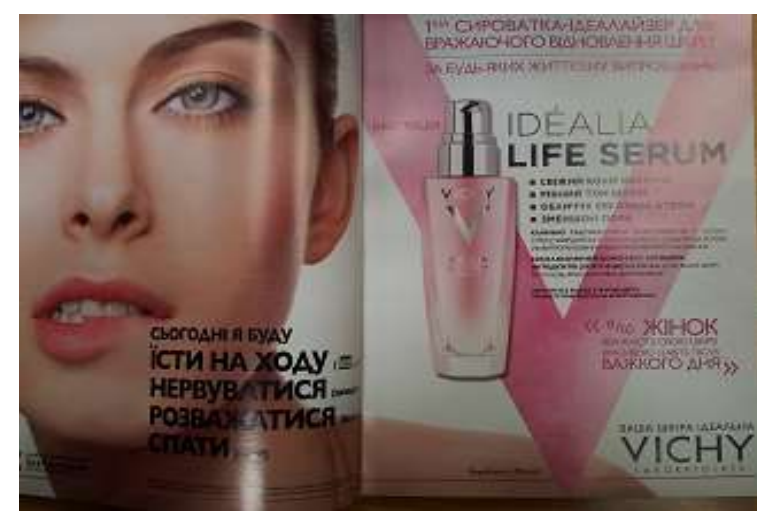

Рис. 5 Припустимо, у Греції продають на вулицях смажені початки молодої кукурудзи, у Камбоджі - смажених павуків, а 3 цого рекламного повідомлення стає зрозумілим, що в Україні на ходу їдять гамбургери (рис. 5).

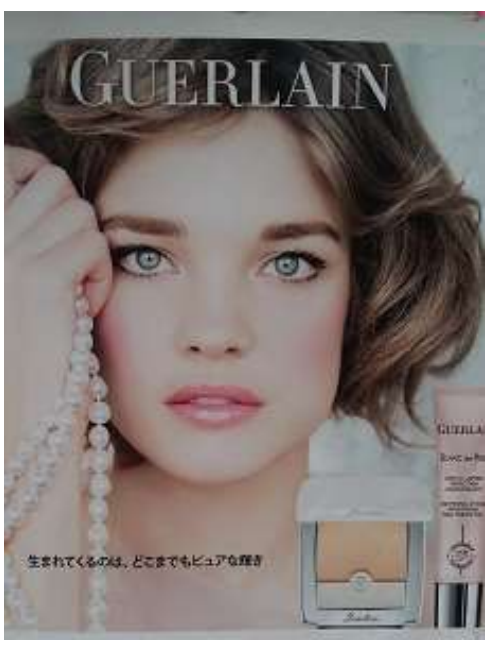

Puc. 6

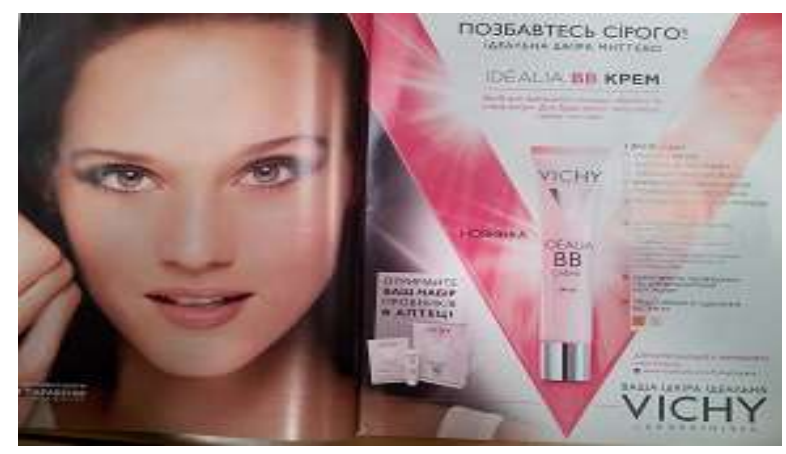

Рис. 7
В японських рекламних повідомленнях відмічаємо використання зображення перлин як еталону кольору і гладкості шкіри для японських жінок (рис. 6). Використання перлин $є$ національнозумовленим зважаючи на всесвітньо відомих японьських жінок ама, професією яких протягом багатьох століть є діставати перлини з морських глибин.
В українських рекламних повідомленнях літери латинського алфавіту відмічаємо здебільшого на позначення бренду (рис. 7) 


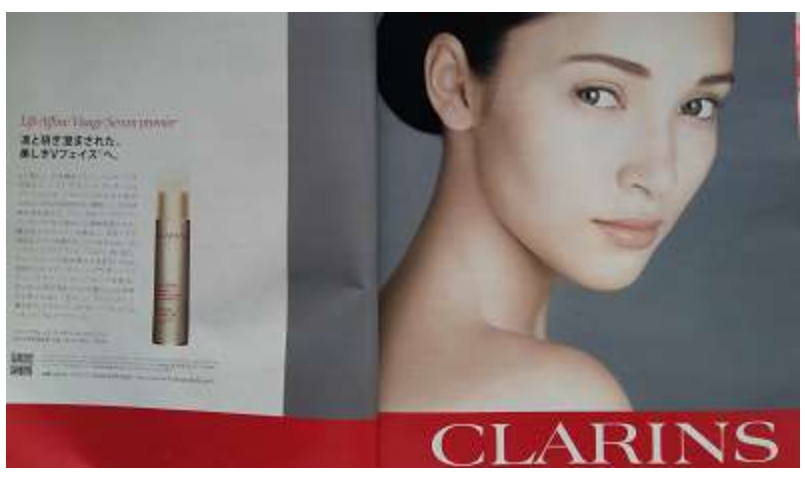

Рис. 8
В японській мові латинські літери позначають певні стандарти буття японських жінок. Часто великі літери поєднуються із запозиченими словами (2,2\%), наприклад: 凛と研ぎ澄まされた、 美しき $\mathrm{V}$ フェイスへ(рис. 8)

У першому прикладі V латиницею означає першу літеру слова victory (перемога), а словосполучення Vフェイス можна перекласти як обличчя перемоги. Але в цьому рекламному повідомленні літера V використана не через зміст слова victory, а через іï форму, яка відображає омріяний тип обличчя усіх японських жінок, що асоціюється 3 формою англійської літери V .

Проаналізувавши фактичний матеріал двох досліджуваних мов, можемо стверджувати, що візуальний компонент (обличчя, фото косметичної продукції тощо) займає більшу частину друкованої площини рекламного повідомлення, ніж текст, що свідчить про домінуюче положення візуального компонента у рекламі косметичної продукції. Поєднання національно-маркованих вербальних i візуальних засобів передачі інформації забезпечує цілісність і зв'язність рекламного повідомлення i комунікативний ефект в українській і японській лінгвокультурах.

Представлене дослідження відкриває перспективи подальших наукових розвідок як у межах лінгвокультурології, так і в суміжних науках, зокрема у когнітивній лінгвістиці, що фокусується на ментальних основах розуміння і продукування мови. 